\title{
Responding to the Reaction: The Draftsman's View
}

\author{
William F. Baxter $\dagger$
}

When the Antitrust Division of the United States Department of Justice undertook to update the 1968 Merger Guidelines, ${ }^{1}$ two goals were set: first, to bring the Guidelines into line with subsequent developments in antitrust law and economics; and second, to reduce the uncertainty surrounding the evaluation of mergers and acquisitions by the Departnent. At the time the revised Guidelines were issued in June 1982, the Departnent felt that it had net those goals. Today, after extensive public scrutiny and debate and after using the Guidelines to review a number of proposed mergers, the Department, or at least the head of the Antitrust Division, remains convinced that the Guidelines meet these objectives. As evidenced by this Symposium, however, there are soine--although apparently a minority-who remain skeptical of, if not hostile to, the Guidelines.

Most, if not all, of the criticisms were foreseen at the time the Guidelines were released. One's evaluation of those criticisms depends primarily on the philosophical and economic assumptions with which one approaclies the Guidelines. To those who view with approval the current trend in antitrust jurisprudence toward a focus on economic efficiency and consuner welfare, many of the criticisms of the Guidelines are unlikely to be persuasive. A number of the other criticisms reflect the debates ainong economists on relatively minor points, such as the extent to which the Herfindahl-Hirschman Index (HHI) is superior to concentration ratios as a measure of concentration. ${ }^{2}$ Still other criticisms reflect differing opimions as to the choice of the precise rules with which to implement the Guidelines' goals. ${ }^{3}$ The Guidelines themselves generally discuss the rationale underlymg the various rules, making it unnecessary to address inany of these criticisms. Furtherinore, several of the participants in this Symposium who are sympathetic to

† Assistant Attorney General in charge of the Antitrust Division, United States Department of Justice. A.B. 1951, J.D. 1956, Stanford University.

1. U.S. Dep't of Justice, Merger Guidelines-1968 (May 30, 1968), reprinted in 2 TRADE REG. REP. (CCH) \& 4510 (Aug. 9, 1982) [hereinafter cited as 1968 Guidelines].

2. E.g., Calkins, The New Guidelines and the Herfindahl-Hirschman Index, 71 CALIF. L. REv. 402 (1983). 445 (1983).

3. E.g., Davidson, The Competitive Significance of Segmented Markets, 71 CALIF. L. Rev. 
the Guidelines have already ably explained and defended nnany aspects of the Guidelines. ${ }^{4}$

Rather than providing an unneeded defense of the Guidelines, this Article briefly describes their underlying assuinptions and provides several prominent exainples of the way in which those assumptions have been translated into the Guidelines' rules. Consequently, this Article addresses, at least indirectly, nany of the issues raised by the commentators. The discussion also should promote a better understanding of the Guidelines and the way the Antitrust Division is using them.

CONSUMER Welfare as the Goal of ANTitrust LaW

Since enactınent of the Sherman $\mathrm{Act}^{5}$ in 1890, commentators have identified numerous goals for the antitrust laws. In recent years, a broad consensus has developed that the antitrust laws are a "consumer welfare prescription"- that is, they are intended to promote economic efficiency, broadly defined. ${ }^{6}$ Nevertheless, a minority continues to insist that antitrust law should reflect more than efficiency concerns. ${ }^{7}$ Primarily, these commentators argue that antitrust jurisprudence should also seek to advance social and political goals. Although the precise concerns vary widely and often are vaguely defined, they include, among others, the deconcentration of economic power, the proinotion of small businesses, and the reallocation of wealth.

Frequently, the antitrust laws' concern for protecting and improving economic efficiency also serves to further social and political goals. However, where there is a conflict, social and political goals should yield to economic considerations primarily for two reasons: first, the statutes theinselves focus on efficiency; and second, nonefficiency goals are too intractable to be used as enforcement standards.

\section{A. The Focus of the Statutes}

An examination of the language and legislative histories of section 1 of the Sherman Act and section 7 of the Clayton Act strongly suggests

4. E.g., Baker \& Blumenthal, The 1982 Guidelines and Preexisting Law, 71 CALIF. L. REv. 311 (1983).

5. Ch. $647, \S 1,26$ Stat. 209 (1890) (codified as amended at 15 U.S.C. $\S 1$ (1976)).

6. Reiter v. Sonotone Corp., 442 U.S. 330, 343 (1979) (quoting R. BoRK, The ANTITRUST Paradox 66 (1978)). See also R. Posner, Antitrust LaW 23, 99-100 (1976); 1 P. Areeda \& D. TURNER, ANTITRUST LAW III 103-1 13 (1978); 4 id. I 906 (1980).

7. See, e.g., Bauer, Government Enforcement Policy of Section 7 of the Clayton Act: Carte Blanche for Conglomerate Mergers?, 71 CALIF. L. REv. 348, 362 (1983); Harris \& Jorde, Market Definition in the Merger Guidelines: Implications for Antitrust Enforcement, 71 CALIF. L. REV. 464, 465-68 (1983); Schwartz, New Merger Guidelines: Guide 10 Governmental Discretion and Private Counseling or Propaganda for Revision of the Antitust Laws?, 71 CALIF. L. REv. 575, 602 (1983). 
a focus on economic efficiency. Section 1 of the Sherman Act prohibits unreasonable "restraint[s] of trade." hibits inergers, the effect of which "in any line of commerce or in any activity affecting commerce in any section of the country . . . may be substantially to lessen competition, or to tend to create a nonopoly." The section 1 standard condemns agreements that restrain outputprecisely the consuner welfare concerns einbodied by the Guidelines. Similarly, Robert Bork has argued persuasively that "competition" and "inonopoly" in section 7 are used as shorthand expressions for effects on consuiner welfare. ${ }^{10}$ Section 7 also expressly limits the inquiry into a inerger's likely effects by requiring that those effects be judged within "a line of commerce in any section of the country"-language that focuses the relevant inquiry on the inerger's effects within the context of economically defined markets.

The legislative histories of the two Acts support this interpretation of their language. ${ }^{11}$ It is true that the legislative history of the CellarKefauver Amendment, ${ }^{i}$ which strengthened the antimerger provisions of section 7 of the Clayton Act, contams several statenents suggesting that at least some ineinbers of Congress beheved the Clayton Act would serve objectives in addition to that of the protection and enhanceinent of economic efficiency. ${ }^{13}$ This does not require a revised interpretation of the statutes, however. As pointed out above, objectives other than consumer welfare frequently can be achieved at the same time economic efficiency is enhanced, and it is not surprising that the political debates surrounding the passage of the amendment reflect this fact. On the other hand, nowhere does the legislative history imdicate that when amorphous social and pohtical goals can only be achieved at the cost of economic efficiency, economic efficiency should be sacrificed.

8. 15 U.S.C. $\$ 1$ (1976).

9. Ch. 323, $§ 7,38$ Stat. 731 (1914) (codified as amended at 15 U.S.C. $§ 18$ (1976 \& Supp. V 1981)). Section 1 of the Sherman Act and $\S 7$ of the Clayton Act embody the same prohibition. Although there has been some confusion in the past, the standards for evaluating mergers under both statutes are the same. See United States v. First Nat'1 Bank \& Trust, 376 U.S. 665 (1964) (using a Clayton Act standard to evaluate the legality of a nierger cliallenged under the Sherman Act); United States v. Philadelphia Nat'l Bank, 374 U.S. 321, 354-55 (1963); 4 P. AREeDA \& D. TURNER, supra note 6, I 906.

10. See, e.g., R. BoRk, supra note 6, at 57-61.

11. Id. at 61-66; R. PosNeR, supra note 6, at 23, 99-100. But see 1 P. AREEDA \& D. TURNER, supra note $6, \uparrow 106$.

12. Ch. 1184,64 Stat. 1125 (1950) (codified as amended at 15 U.S.C. $\S 18$ (1976 \& Supp. V 1981)).

13. See generally Brown Shoe Co. v. United States, 370 U.S. 294, $315-23$ (1962); R. POSNER, supra note 6 , at $99-100$. 


\section{B. Intractability of Nonefficiency Goals}

Even if the Sherman and Clayton Acts and their legislative histories may be interpreted to allow antitrust policy to be guided by considerations other than economic efficiency, economic efficiency provides the only workable standard from which to derive operational rules and by which the effectiveness of such rules can be judged. ${ }^{14}$ Efficiency gams or losses from mergers are at least theoretically calculable, and economic theory provides a basis for making a priori determinations as to the circumstances under which mergers are likely to reduce economic efficiency. The same camrot be said for social and political standards. ${ }^{15}$ Generally, noneconomic standards are stated in vague, subjective terms. As a result, it is impossible to articulate well-defined operational rules based on such standards and to evaluate the success or failure of the rules in achieving their objectives. ${ }^{16}$ That is, while one can estimate the approximate economic costs and benefits of a merger and readily compare the two, there is no objective ineasure for valuing social and political costs and benefits.

Furthermore, if there were operational rules for proinoting some well-defined social or political goal, it would still be unclear whether those benefits were worth the economic costs. First, because it may be difficult to convert noneconomic benefits into economic terms, it is impossible to compare those benefits to the economic costs that inust be incurred to achieve them. Second, although real and generally estimable, thc economic costs of achieving those noneconomic goals would not be exphicit. Direct taxes and subsidies would be less costly (and politically inore honest) inethods for achieving social and pohtical goals. ${ }^{17}$ Congress is far better suited politically than courts and prosecutors to determine whether or not the benefits of social and political engineering (such as that contenplated by Professor Schwartz ${ }^{18}$ and others $^{19}$ ) are worth the toll on economic efficiency. ${ }^{20}$

14. See Baxter, Separation of Powers, Prosecutorial Discretion and the "Common Law" Na. ture of Antitrust Law, 60 TEX. L. REv. 661, 693 (1982).

15. 1 P. AREeDA \& D. TURNER, supra note 6, ๆ 111-112.

16. It is ironic that those commentators who condemn the Guidelines for their exclusive focus on economic concerns are frequently the same ones who criticize the Guidelines for being too indefinite. See Harris \& Jorde, supra note 7, at 485; Schwartz, supra note 7, at 595 . It is difficult to square these two criticisins.

17. See, e.g., R. POSNER, supra note 6, at' 19-20.

18. Schwartz, supra note 7, at 602.

19. E.g., Harris \& Jorde, supra note 7, at $465-68$.

20. The failing firm doctrine is potentially one exception, however, to the rule that merger analysis focuses solely on economic efficiency. See Baxter, Remarks: The Failing Firm Doctrine, 50 ANTITRUST L.J. 247, 251-52 (198I); R. POSNER, supra note 6, at 20-22. As indicated in the Guidelines, some have described the doctrine as a balancing of coinpetitive and noncompetitive concerns. U.S. Dep't of Justice, Merger Guidelines \& V(B) n.54, 47 Fed. Reg. 28,493, 28,502 n.54 (1982), reprinted in 71 CALIF. L. REv. 649, $665 \mathrm{n} .54$ (1983) [heremafter cited without cross-refer- 


\section{II}

\section{The Guidelines AND ECONOMIC ANALysis}

Operational rules grounded in a concern for economic efficiency are tractable as well as consistent with the spirit and letter of the antitrust laws. The "unifying theme" of the revised Guidelines is that "mergers should not be permitted to create or enhance 'narket power' or to facilitate its exercise."21 Market power is the ability of a seller or group of sellers acting in concert profitably to raise prices above competitive levels. By raising prices above competitive levels, the exercise of market power generates allocative mefficiences. ${ }^{22}$

Mergers can create, enhance, or facilitate inarket power by: (1) creating or enlarging a single dominant firm that, actimg alone, is able to raise price profitably; ${ }^{23}$ (2) altering the size distribution of firms im the market (i.e., mcreasing concentration), which may increase the ability of a small number of firms acting im concert to raise price profitably, ${ }^{24}$ (3) eliminating a potential coinpetitor that otherwise would act as a restraint on the exercise of market power, ${ }^{25}$ (4) increasing the difficulty of entry to future entrants; ${ }^{26}$ and (5) facilitating collusive pricing by inembers of the market in ways other than by reducing their number. ${ }^{27}$ To evaluate a given merger then, one should be able directly or indirectly to measure market power. As has been explained im several articles, direct measurement is extremely impractical, if theoretically possible. ${ }^{28}$ As an alternative the law has developed, and the Guidelines have refined, the concept of market definition which provides an indirect measure of market power.

\section{A. Market Definition}

The most innovative and controversial aspect of the Guidelines is their approach to market definition. As defined by the Guidelines:29

ence as Guidelines]. Nevertheless, by limiting the availability of the defense to situations in which the only alternative to the merger is the exit of a competitior, the Guidelines atteinpt to assure that the defense will not reduce consumer welfare.

21. Guidelines \& I, 47 Fed. Reg. at 28,493, 71 CALIF. L. Rev. at 649.

22. For a standard textbook treatment, see F. Scherer, Industrial Market Structure and Economic Peformance 14-20 (2d ed. 1980).

23. Guidelines $\S \operatorname{III}(\mathrm{A})(2), 47$ Fed. Reg. at $28,497,71$ CALIF. L. Rev. at 657.

24. Id. $\$ \operatorname{III}(\mathrm{A}), 47$ Fed. Reg. at $28,497,71$ CALIF. L. Rev. at 655 .

25. Id. $\S$ IV(A), 47 Fed. Reg. at $28,499,71$ CALIF. L. Rev. at 660.

26. Id. $\S$ IV(B), 47 Fed. Reg. at 28,500, 71 CALIF. L. Rev. at 662.

27. Id. \& IV(B)(3), 47 Fed. Reg. at 28,501, 71 CALIF. L. REv. at 664-65.

28. See Ordover \& Willig, The 1982 Department of Justice Merger Guidelines: An Economic Assessment, 71 CALIF. L. Rev. 535 (1983); Landes \& Posner, Market Power in Antitrust Cases, 94 HARV. L. REV. 937 (1981).

29. Guidelines \& II m1.6 \& 11, 47 Fed. Reg. at 28,494 n.6, 28,495 n.11, 71 CALIF. L. REv, at 650 n.6, 651 n.11. 
a market consists of a group of products and an associated geographic area such that (m the absence of new entry) a hypothetical, unregulated firm that made all the sales of those products in that area could increase its profits through a small but significant and nontransitory increase in price (above prevailing or likely future levels).

The idea behind this rather imposing definition is quite simple. The merger of two sellers of a product in an area can create a significant danger of collusive price increases only if the inerger of all sellers of that product in that area would cause price to rise significantly. If the only seller (i.e., a monopolist) of that product in that area would not have market power, then reducing the number of sellers cannot pose a problem. ${ }^{30}$

Under the Guidelines, a inarket is defined by considering a series of concentric groups of products and areas and determining, as to each group, whether a single seller of the group of products in the area would find it profitable to increase price significantly. If the answer is yes, then the group of products and the area are considered to be a inarket. While this inquiry may produce a number of markets from which one must be chosen as the relevant inarket, the Guidelines indicate that the sinallest market generally is to be considered the relevant one. $^{31}$

Commentators have criticized the Guidelines' approach to market definition on the ground that it is too theoretical and is therefore of no practical value in inerger cases. ${ }^{32}$ Similarly, it has been charged that because the Guidelines' approach to market definition is so theoretical, it will be difficult to determine a priori whether the Division will challenge a merger. ${ }^{33}$ Fimally, some charge that the Guidelines are arbitrary in their choice of a one year, $5 \%$ price increase as the first approximation of whether a significant and nontransitory imcrease im the price of a group of products im an area would be profitable. ${ }^{34}$ None of these criticisms is persuasive. ${ }^{35}$

30. Williamson, Vertical Merger Guidelines: Interpreting the 1982 Reforms, 71 CALIF. L. REV. 604, 614-15 (1983).

31. For an example involving the coal industry, see U.S. DEP'T OF JUSTICE, COMPETITION IN the Coal Industry ch. 3 (Deceinber 1982) [hereinafter cited as The CoAl Report]. For a discussion of how this can be done, see Werden, Market Delineation and the Justice Department's Merger Guidelines (forthcoming in 1983 DUKE L.J.).

32. E.g., Harris \& Jorde, supra note 7, at 476.

33. E.g., Schwartz, supra note 7, at 587.

34. E.g., Areeda, Justice's Merger Guidelines: The General Theory, 71 CALIf. L. Rev. 303, 307-08 (1983).

35. Several commentators have also noted that the Guidelines seem to make the same mistake as that made in United States v. E.I. du Pont de Nemours \& Co. (Cellophane), 351 U.S. 377 (1956). See, e.g., Baker \& Blumenthal, supra note 4, at 322 n.54. These commentators note that if one applies the Guidelines' approach (which basically attempts to gauge market elasticity) in a context where niarket power is already being exercised, there will be a tendency to define the 
First, one of the greatest problems with the courts' approach to market definition in the past has been its ad hoc character. Frequently, the courts have analyzed a number of factors without understanding why those factors and not some others are relevant. On the other hand, the Guidelines provide, arguably for the first time, an analytical framework for defining markets. It will of course be true that available data may not allow a direct determination of whether a significant, nontransitory increase in price would be profitable. However, where such data are not available, there is at least a theoretical framework for analyzinig the relevance of indirect or second-best evidence.

Similarly, by illuminatimg the overall process of market definition, the Guidelines should increase certainty for firms contemplatimg mergers. No one can argue that the approach to market definition employed by the courts is any clearer than the Guidelines' approach. In addition, the Guidelines themselves provide an illustrative hist of relevant evidence that the Division will use to determine indirectly whether an imcrease in price will engender significant substitution..$^{36}$

It also should be pointed out that the costs of absolute certainty would be too high. In drafting guidelines, one must balance the benefits of certainty against the loss in robust analysis. The Guidelines were intended to clarify, and have in fact clarified, the Division's approach to market definition; nevertheless, because the definition of relevant markets depends so inuch on the facts of a given case, it would be impossible to state the Division's approach to market definition in sufficient detail so that everyone could predict with certainty the way in which the Division will define a market under every possible scenario.

Finally, the criticism of the Guidelines' use of " $5 \%$, one year" to

Inarket too broadly. It can be shown that a firm or firms effectively exercising market power will set price in the elastic region of their deinand curve, and intuitively, one can posit that if the firms exercising market power could raise price profitably, they would already have done so.

The Division was aware of this problem in drafting the Guidelines; however, it was not clear that anything needed to be done about it. The problem in the Cellophane case can lead to erroneous analysis under $\S 2$ of the Sherman Act because in such a case it is necessary to determime whether a firm is presently exercising narket power in order to determine whether corrective action is necessary to reduce that power. On the other hand, horizontal merger analysis under $\$ 7$ of the Clayton Act is concerned with the probability that a merger will decrease competition in the future. If the firms in the inarket are colluding before the merger but are exercising their market power imperfectly, then a 5\% price increase inay still be profitable for a hypothetical monopolist and so the Guidelines' approach frequently will define a market within which to evaluate a merger effectively. If the firm or firms are exercising their market power imperfectly so that a 5\% price increase will not be profitable, however, it may be mappropriate to challenge the merger. Prohibiting the inerger likely will have no effect on the exercise of narket power, but the prohibition will eliminate any possibility that the merger may disturb the status quo and invigorate competition or that the merger will achieve efficiencies which can reduce the monopoly price. Morcover, if indirect evidence indicates that a merger is likely to prevent prices from falling for a longer period than otherwise would be the case, the inerger still could be challenged.

36. Guidelines $\S \mathrm{II}(\mathrm{A}), 47 \mathrm{Fed}$. Reg. at $28,495,71$ CALIF. L. Rev. at 651. 
determine the relevant markets is unwarranted. As the Guidelines note, those numbers are used only as a "first approximation." Generally, if a price increase of that magnitude is profitable, one can be confident that the product and area constitute a market. While those nuunbers represent the general standard, the Division may determine that because of peculiar facts in a given case some other numbers will provide a more accurate standard for defining the market. ${ }^{37}$ The selection of any numbers is inherently arbitrary (there is no reason that $6 \%$ and ten months would be inherently less reasonable); however, given the flexibility of the Guidelines, the use of the first approximation should not lead to arbitrary results.

\section{B. The Herfindahl-Hirschman Index and the Thresholds}

After having defined the relevant market, the Division must analyze the effect of the merger in that market. The primary, though by no means exclusive, predictor of the likelihood of collusion in a market is the size distribution of sellers' market shares. Tacit or explicit collusion is unlikely to occur unless a relatively small number of sellers account for a relatively large portion of the market. ${ }^{38}$ Accordingly, the Guidelines first consider the size distribution of firms after a merger and the change in size distribution brought about by the merger. The Guidelines use the Herfindahl-Hirschman Index (HHI) (the sum of the squares of the market shares of sellers in the market) to summarize size distribution or concentration. ${ }^{39}$

A great deal of attention has been paid to the fact that the Guidelines use the HHI, rather than the 4-firm concentration ratio (CR4) to measure concentration. The intensity of the furor, however, is greatly disproportionate to the significance of the choice. The HHI and the CR 4 are highly correlated, ${ }^{40}$ and the choice between the two generally will not make much difference. Moreover, no summary measure of nuarket structure can claim to be the only theoretically or empirically correct measure. Understanding that the HHI is no panacea, the Division nevertheless chose the HHI over the CR4 for three reasons.

First and most important, the CR4 ignores the size of fifth and smaller firms as well as the relative size of the top four, and both of these factors can have an important effect on the likelihood of collusion. Unless the four largest firms control a very large proportion of

37. See, e.g., The COAl Report, supra note 31, at 22-24.

38. See, e.g., Fraas \& Greer, Market Structure and Price Collusion: An Empirical Analysis, 26 J. Indus. Econ. 21 (1977); Hay \& Kelley, An Empirical Survey of Price Fixing Conspiracies, 17 J.L. \& ECON. 13 (1974).

39. Guidelines $\S \operatorname{III(A),~} 47$ Fed. Reg. at 28,497, 71 CALIF. L. Rev. at 655.

40. See, e.g., F. SCHERER, supra note 22 , at $58 \&$ n. 52 (and sources cited therein). 
the market, firms other than the top four would be involved in any successful agreement. ${ }^{41}$ There is also some reason to believe that collusive agreeinents are easier to inaintain if one or two of the participants are significantly larger than others. ${ }^{42}$ The HHI is sensitive to this factor, while the CR4 is not. Second, the HHI is a very simple and convemient tool for measuring the effect of a merger on market structure and the likelihood of collusion. A inerger increases the HHI by an anount equal to twice the product of the shares of the inerging firms, and the product of the shares is an informative and convemient way in which to assess that effect. Finally, the theoretical foundation of the HHI is the inost solid of any summary ineasure of narket structure. While theoretical work on collusion has not progressed to the point that it offers coinpelling support for any particular measure of market concentration, it does suggest use of the $\mathrm{HHI} .^{43}$

Given the extensive nature of market definition under the Guidelines, the inagnitude of the postinerger HHI and of the change wrouglit in $\mathrm{HHI}$ provide a very informative, although indirect, ineasure of the likelihood of collusion in a inarket. It is appropriate then to use that measure as a "first cut" in merger analysis: the HHI without more may indicate that further inquiry is not warranted. As a result, the Guidelines establish postmerger HHI thresholds as trigger points.

The selection of thresholds has itself been the subject of controversy. One concern is that in establishing thresholds at all, the Division may be relying excessively on sunall numerical differences that are not very important. ${ }^{44}$ This concern is wholly unjustified. The Guidelines specifically state that "cases falling just above and just below a threslold present comparable competitive concerns." 45 The difference between an HHI of 950 and 1050 is slight, and the Division will treat it as such. In such a marginal case, the Division will not necessarily rest its decisions on whether the merger falls above or below the thresliold. As the Guidelines inake clear, numerical measures of coneentration are not their sole focus.

In addition, soine have taken issue with the particular HHI thresholds chosen. The present state of the theoretical and einpirical literature on collusion precludes a rigorous basis for any particular thresholds. Those used in the Guidelines were adopted because they were consistent with the experience of those in the Division and also

41. Conspiracies that have been detected and prosecuted generally have involved more than four firms. See, e.g., Fraas \& Greer, supra note 38, at 34; Hay \& Kelley, supra note 38, at 22.

42. See, e.g., Stigler, $A$ Theory of Oligopoly, 72 J. Pol. EcoN. 44 (1964).

43. See Ordover, Sykes \& Willig, Heffindahl Concentration, Rivalry, and Mergers, 95 HARV.

L. REV. 1857 (1982); Stigler, supra note 42.

44. Calkins, supra note 2 , at 404 .

45. Guidelines § III(A), 47 Fed. Reg. at 28,497, 71 CALIF. L. REv. at 656. 
with empirical literature. The thresholds of 1000 and 1800 in the Guidelines correspond roughly to CR4's of 50 and 70.46 Economists have frequently identified a CR4 of about 50 as the point at which the likelihood of anticompetitive behavior becomes significant, and a considerable amount of empirical work lends support for this threshold. ${ }^{47}$ A CR4 of 70 or 75 has often been used as the point at which the likelihood of anticounpetitive conduct becomes very signficant, and the latter figure was used in the 1968 Guidelines. ${ }^{48}$ There also is some enpirical support for this figure. ${ }^{49}$ However, the Division does not consider the thresholds of 1000 and 1800 to be magic numbers. Shightly different thresholds would have been equally reasonable.

The Guidelines also have a leading firm proviso to catch inergers that may create a danger of inarket power but that do not reach the HHI thresholds. As indicated above, in addition to making the collective exercise of unarket power easier, inergers also can increase a single competitor's ability to exercise market power unilaterally by increasing his size. Sone would argue that this is the only time one should be concerned with inergers between horizontal competitors. ${ }^{50}$ The leading-firm proviso, then, is desigued to prevent the possibility of enhancing single-firm inarket power that has no effective coinpetitive check from small rivals. The proviso indicates that the Division will challenge the acquisition of a firm with a $1 \%$ market share when the acquiring firm has at least a $35 \%$ share and has a nnarket share at least twice as large as the next largest competitor.

Again, the Guidelines have been criticized for the choice of the $35 \%$ threshold. ${ }^{51}$ Generally, this percentage is criticized as too large because a smaller percentage may also create a danger of inarket power. As with the selection of HHI thresholds in those cases involving

46. Under certain assumptions about the distribution of market shares, the CR4's that correspond to HHI's of 1000 and 1800 would be 50.8 and 67.3. See Scarbrough \& Pfunder, New Merger Guidelines Not Always Less Restrictive, Legal Times (Washington), Jan. 10, 1983, at 19, 27.

47. There is an extremely large body of empirical work relating market performance, measured by profits, to market concentration. Although the data used has serious limitations and the imphications of the studies are open to dispute, these studies generally have been argued to establish that high levels of concentration lead to collusion. For an excellent summary, see Weiss, The Concentration-Profits Relationship and Antitrust in Industrial CONCENTRATION: THE NEw LEARNING 184 (H. Goldschmid, H. Mann \& J. Weston eds. 1974). Some studies have attempted to identify a single critical level of concentration at which collusion occurs. They generally have found a critical CR4 in the 50's. See, e.g., White, Searching for the Critical Industrial Concentration Ratio: An Application of the "Switching of Regimes" Technique, in STUDIES IN NONLINEAR Estimation 61, 71-72 (S. Goldfeld \& J. Quandt eds. 1976). A recent study found two critical levels of concentration: CR4's of 46 and 68. Bradburd \& Over, Organizational Costs, "Sticky Equilibria," and Critical Levels of Concentration, 64 REv. ECON. \& STAT. 50 (1982).

48. 1968 Guidelines, supra note 1, para. 6, 2 TRADE REg. ReP. (CCH) at 6884.

49. See id.

50. See, e.g., R. BORK, supra note 6.

51. E.g., Calkins, supra note 2, at 421-22. 
the danger of collusion, the selection of a threshold for the leading-firm proviso was somewhat arbitrary. However, the Division decided that danger from slight increases in single-firm nnarket power was not significant when a single firm held less than $35 \%$ of the market. Furthermore, limiting growth through inerger at market share levels below $35 \%$ might result im the sacrifice of efficiencies im some inarkets. It was the judgment of the Division that at about 35\%, the danger of market power becomes sufficiently great to overwhelm any concern for the potential efficiencies that might be lost from prohibiting a leading firm merger.

\section{The Other Factors}

While the degree of concentration in a market provides a great deal of information concerning the probability that a inerger will create or enhance market power, a number of other variables affect the ability of firms to exercise market power. ${ }^{52}$ These variables, discussed in the Guidelimes under the topic "Other Factors," which sellers can reach and mamtain collusive agreements. The individual factors listed are fairly standard and generally uncontroversial. Nevertheless, two frequent criticisins are that the Guidelimes fail to assign relative weights to the factors ${ }^{54}$ and that the list of factors has excluded economically relevant factors. ${ }^{55}$

Certainly the assignment of relative weights would have been desirable if it had been feasible. However, after the Division had extensively analyzed all of the factors affecting the likelihood of collusion, it ultimiately decided that the Guidelines could do little inore than provide an illustrative list of the most significant factors and discuss the Division's analysis of those factors. Apart from market concentration,

52. Guidelines § III(C), 47 Fed. Reg. at 28,498-99, 71 CALIF. L. Rev. at 657-60. In addition to these "other factors," the Guidelines pay particular attention to the cxtent to which collusion would be rendered unprofitable by the actions of firms not currently selling in the relevant market. Such firms are divided into two categories by the Guidelines-those that could begin selling quickly and easily using existing facilities and those that could begin selling fairly quickly and easily by constructing new facilities. The infuence of the former type of firms is addressed under the heading "production substitution." The Guidelines indicate that firms that are not presently selling the relevant product in the relevant area will nevertheless be considered to be in the relevant market if they have "existing productive and distributive facilities that could easily and econoinically be used to produce and sell the relevant product" im a short period of time in response to a small increase in price. Id. $\S \mathrm{II}(\mathrm{B})(1), 47 \mathrm{Fed}$. Reg. at $28,495,71$ CALIF. L. REv. at 652 . The second category is called "entry" and the Guidelines indicate that "[i]f entry into a market is so easy that existing competitors could not succeed in raising price for a significant period of time, the Department is unlikely to challenge mergers in that market. $I d$. §III(B), 47 Fed. Reg. at $28,498,71$ CALIF. L. Rev. at 657.

53. Id. § III(C), 47 Fed. Reg. at 28,498-99, 71 CaLIF. L. Rev. at 657-60.

54. E.g., Schwartz, supra note 7, at 595.

55. E.g., Davidson, supra note 3, at $445-47$. 
the factors that affect the likelihood of collusion are unquantifiable in any apparent way, and their effect on the probability of collusion will vary greatly depending on the particular circumstances. Indeed, while one of the factors may increase the danger of collusion under certain circumstances, the same factor may make collusion less likely under other circumstances. ${ }^{56}$ Thus, the Division ultimately concluded that there was no alternative to a careful, case-by-case analysis of these factors.

Although the Division assigns no particular weight to any or even to all of these factors, it should be understood that they may be important in a significant fraction of cases. The Division is unlikely to challenge mergers in markets with an HHI just above 1000 unless other factors imdicate that collusion is significantly probable. Moreover, even if the postmerger HHI will exceed 1800 and will be increased by more than 100, the Division may not challenge the merger if these other factors indicate that collusion would be clearly implausible. In assessimg the probability of collusion, it may turn out that factors other than those listed in the Guidelines are significant. ${ }^{57}$ Several factors that could be important in particular cases were not included in the Guidelines because they were not of sufficiently general importance.

On the other hand, this should not be taken to mean that any factor will be considered by the Division in analyzing mergers. One of the primary weaknesses of early section 7 jurisprudence was the use of numerous, frequently irrelevant factors in analyzing mergers. A review of the Report of the Attorney General's National Committee to Study the Antitrust Laws reveals the rather diffuse nature of early analysis under

56. For example, similiarities or differences in the products and locations of the merging firms may increase or decrease the likelihood of collusion depending on other factors in the case. Guidelines § III(C)(1)(c), 47 Fed. Reg. at 28,498, 71 CALIF. L. REV. at 658.

57. One of the factors that several of the Symposium's participants have alluded to is the rate of growth of demand. E.g., Baker \& Blumenthal, supra note 4, at 336 n.93. Related to demand growth is the rate of teclinological cliange in the market. Although the Division considered including both factors in the list, neither ultimately was included. There is a significant relationship between product heterogeneity, cost differences among firms in the market, growth in market demand, and teclınological cliange in the market. If there is rapid technological change, the market is likely to experience rapid growth in demand, and to be composed of lieterogenous products and of firms having different cost structures. If all four of these factors were included in the list, the Guidelines might have created a misimpression that the Division would necessarily analyze the merger differently if several of these related factors were present rather than only one. Furthermore, there are problems associated with identifying and measuring future technological change and differences in cost structures. As a result, the Division decided to include only one factor, product heterogeneity, in the list. However, where there is substantial, clear evidence of rapid technological change in the processes by which a homogeneous product is made, or of significant growth in demand for a homogeneous product, that evidence may be considered relevant in the analysis of a merger. 
section 7.58 As with the Supreme Court's analysis in Brown Shoe Co. v. United States, ${ }^{59}$ the legality of a merger was to be judged on the basis of an open-ended list of factors without any central theme. Conceivably anything, including perhaps the psychic health of other sellers, could be considered.

The fact that other factors can be considered does not mean that the Guidelines will permit an unfocused inquiry. The Division will consider only those factors that, according to economic theory or empirical evidence, relate to the ease and profitability of collusion. ${ }^{60}$ An industry trend toward concentration is not a factor that will be considered, even though it has been used in the past. First, the trends cited by the courts in the past often have been illusory or misleadimg. ${ }^{61} \mathrm{~A}$ trend (for example, that in the grocery retailing imdustry) may refiect changes in teclinology or in tastes rather than the likelihood of collusive conduct. If those changes are fundamental and if mergers are prohibited, the industry inay be forced to adjust to those changes in ways that are less efficient than through inergers. This would be particularly unfortunate if the trend toward concentration, even though accomplished through mergers, would not result in a level of concentration high enough to make collusion a concern. Second, there is no evidence that the failure to consider trends may stampede firms into merging at the earliest possible time lest they delay until concentration has reached a level which would prevent further nergers in that market. Finally, if there is no indication that a particular proposed inerger creates a significant likelihood of lessening competition, it is unacceptable to sacrifice the potential efficiencies associated with the merger based solely on inere speculation that other inergers in the future might lessen competition. The presumption that inarket transactions are efficient should be abandoned only when likelihood of collusion is clear and proximate, not when it is speculative and remote.

\section{CONCLUSION}

This Article has touched only briefly on a few of the issues raised by this Symposinin. The Guidelines themselves deal with most of those issues either explicitly or implicitly. Many imvolve judgunent calls that are defensible, but at the same time are inherently open to secondguessing. A few of the issues go to the very foundation of the antitrust laws, and thus are beyond the scope of this Article.

58. Attorney General's National Committee to Study the Antitrust laws, RePORT 115-28 (S. Barnes \& S. Oppenheim co-chairs 1955).

59. 370 U.S. 294 (1962).

60. Guidelines $\S \mathrm{III}(\mathrm{C}), 47 \mathrm{Fed}$. Reg. at 28,498, 71 CaLIF. L. Rev. at 658.

61. See United States v. Von's Grocery Co., 384 U.S. 270, 273-74, $277-78$ (1966). 
Although none of the criticisms made by other authors in this Symposium seriously threaten the viability of the Guidelines, or even come as a surprise, symposia such as this are healthy. They reflect an appropriate scrutinizing of government policy and its underlying assumptions. It is hoped that further study and deeper understanding of industrial organization will result. Guided by such advances im the understanding of markets, mergers, and concentration, future revisions of the Guidelines will be able even more effectively to proinote and protect consumer welfare. 